\title{
PERSPEKTIF GURU TENTANG PENGEMBANGAN SMA DI TANGERANG PADA MASA PANDEMI COVID-19.
}

\author{
Muh Turizal Husein \\ abituriza168@gmail.com \\ Fakultas Agama Islam, Universitas Muhammadiyah Tangerang, Jln. Perintis Kemerdekaan I \\ Babakan No.33 Tangerang-Banten \\ Sahlani \\ Sahlaros44yahoo.com \\ Fakultas Agama Islam, Universitas Muhammadiyah Tangerang, Jln. Perintis Kemerdekaan I \\ Babakan No.33 Tangerang-Banten
}

\begin{abstract}
This article focuses on the challenges of teachers at high schools related to the digitalization process in school development during the Covid-19 pandemic. In addition to being an intrapersonal prerequisite for teaching with technology and changing attitudes towards learning and teaching, it is a prerequisite for schools as part of a learning organization. This research is a qualitative research with a qualitative interview study of 10 participants or teachers. This was done to identify challenges for teachers, the role of ship principals, and collaboration among stakeholders. The strategy of teaching methods using technology proved to be a clear agenda by school principals regarding reliable technology infrastructure and also the willingness of teachers to use teaching methods.
\end{abstract}

Keyword : High School, Covid-19 Pandemic, Digitalization

\section{ABSTRAK}

Artikel Ini Berfokus Pada Tantangan Guru Di Sekolah menengah atas berkaitan dengan proses digitalisasi dalam pengembangan sekolah selama pandemika Covid-19. Selain menjadi prasyarat intrapersonal untuk mengajar dengan teknologi dan perubahan sikap belajar dan mengajar, prasyarat mengenai sekolah sebagai bagian dari organisasi pembelajaran. Penelitian ini adalah penelitian kualitatif dengan sebuah studi wawancara kualitatif terhadap 10 orang peserta atau guru. Ini dilakukan untuk mengidentifikasi tantangan bagi guru, peran kepala sekolah kapal, dan kerjasama antar pemangku kepentingan. Strategi koping dan metode pengajaran dengan menggunakan teknologi terbukti menjadi agenda yang jelas oleh kepala sekolah sehubungan dengan infrastruktur teknologi yang andal dan juga kesediaan guru untuk menggunakan metode pengajaran.

Kata kunci: Sekolah Menegah Atas, Pandemi Covid-19, Digitalisasi.

\section{A. Pendahuluan}

Penutupan sekolah secara nasional akibat pandemi Covid-19 pada paruh pertama tahun 2020 merupakan hal yang tidak umum bagi masyarakat Indonesia. Mirip dengan negara-negara di dunia lainnya, penutupan fasilitas sekolah berlangsung serempak sejak pandemi covid-19 melanda. Pemerintah menginstruksikan penutupan ini serta merumahkan seluruh siswa mulai PAUD/ TK, SMP, SMA/SMK hingga perguruan 
tinggi dan melaksanakan kegiatan belajar mengajar di rumah, terhitung mulai 16 sampai dengan 29 Maret 2020. Pengajaran di kelas dihentikan di semua wilayah Kota dan Kabupaten di Indonesia untuk melindungi siswa, mahasiswa, guru, dosen dan personel lainnya dari infeksi virus Covid-19. Awalnya, sekolah dijadwalkan untuk dibuka kembali pada April 2020, tetapi pandemi yang sedang berlangsung memaksa pembuat kebijakan untuk meminta beberapa perpanjangan. Bahkan saat ini awal Juli 2021 beberapa kota di Pulau Jawa dan Bali sedang diterapkan Pemberlakukan Pembatasan Kegiatan Masyarakat Darurat (PPKM Darurat). Di sekolah, guru dan administrasi mulai menerapkan pengajaran online atau daring. Perubahan yang demikian cepat dari pembelajaran dan pengajaran offline ke online merupakan tantangan besar bagi semua pemangku kepentingan dalam pembangunan sekolah, ini menurut Roff dalam Jan Delcker \& Dirk Ifenthaler disebut sebagai transformasi sadar dan sistematis dilakukan oleh para pemangku kepentingan, terutama untuk guru ${ }^{1}$.

Artikel ini berfokus pada tantangan guru selama proses digitalisasi di sekolah dan strategi koping dengan penekanan khusus pada pandemi Covid-19. Kemampuan intrapersonal ini merupakan prasyarat untuk mengajar dengan teknologi seperti yang dijelaskan oleh Mishra dan Koehler ${ }^{2}$ dalam TPACK (Technological Pedagogical Content Knowledge), perubahan dalam pembelajaran dan

${ }^{1}$ Jan Delcker \& Dirk Ifenthaler (2020): Teachers' perspective on school development at German vocational schools during the Covid-19 pandemic, Technology, Pedagogy and Education, DOI: $10.1080 / 1475939 X .2020 .1857826$

${ }^{2}$ Mishra, P., \& Koehler, M. J. (2008). Introducing Technological Pedagogical Content Knowledge. Paper Presented at The Annual Meeting of American Educational Reseacrh Association. New York. pengajaran sikap terkait teknologi ${ }^{3}$. Ini semua menjadi prasyarat dan kelengkapan dari infrastruktur berupa teknologi yang harus dimiliki sekolah misalnya, jumlah perangkat seluler seperti ketersediaan jaringan internet yang memedai yang harus tersedia di sekolah atau adanya rencana pengembangan digital di seluruh sekolah.

Tujuan dari penelitian ini adalah untuk mengidentifikasi pengaruh paling umum dari Covid-19 di sekolah menengah atas. Strategi koping dan solusi yang dikembangkan selama pandemi covid-19 dapat bermanfaat untuk sekolah lain di luar pandemi atau situasi yang menyebabkan stres atau trauma psikologis lainnya .

\section{B. Sekolah Menengah Atas (SMA) 1. Kondisi SMA}

Dalam beberapa tahun terakhir, sekolah-sekolah di Indonesia belum dapat secara sistematis mengintegrasikan secara luas Teknologi Informasi dan Komunikasi (TIK) ke dalam pengajaran, pembelajaran dan pengembangan sekolah. Infrastruktur teknologi untuk mendukung TIK di sekolah kurang berkembang dibandingkan dengan negara lain, sebut saja Singapore, China dan Jepang. Permasalahan koneksi jaringan salahsatunya selalu menjadi permasalahan utama ketika siswa dan sekolah memberlakukan pembelajaran oneline. Jika dilihat secara presentase hanya sebagian kecil saja sekolah yang dilengkapi dengan jaringan kecepatan tinggi. Temuan mengusulkan bahwa infrastruktur teknis yang hilang adalah salah satu alasan kompetensi TIK siswa yang kurang berkembang. Para Guru di Indonesia sangat jarang menggunakan teknologi daripada rekan mereka di negara-

${ }^{3}$ Ifenthaler, D., \& Schweinbenz, V. (2013). The acceptance of tablet-PCs in classroom instruction:The teachers' perspectives. Computers in Human Behavior Journal, 29(3), 525534. doi:10.1016/j.chb.2012.11.004 
negara lain. Bahkan Kementerian Pendidikan dan Kebudayaan (Kemendikbud) mengungkapkan 60 persen guru di Tanah Air belum menguasai Teknologi Informasi dan Komunikasi (TIK). Padahal, Kemendikbud menyebut Indonesia sekarang membutuhkan sumber daya manusia (SDM) yang unggul ${ }^{4}$. Sebagai hasilnya, hampir sebagian besar siswa menunjukkan TIK yang sangat rendah. Alasan lain TIK tidak hadir di sekolah-sekolah seperti di negara lainnya adalah tidak adanya TIK dalam program pendidikan guru dan kurikulum terbaru. Sebagai konsekuensi dari kurangnya formalisasi dalam pendidikan guru program dan kurikulum, pemangku kepentingan di sekolah sering tidak melihat perlunya investasi sebagian dari anggaran mereka untuk infrastruktur atau pengembangan profesional kompetensi TIK guru. Situasi di sekolah-sekolah di Indonesia khususnya di Tangerang sangat kontras dengan status Kota Industri dan wilayah penyumbang terbesar APBD Provinsi Banten.

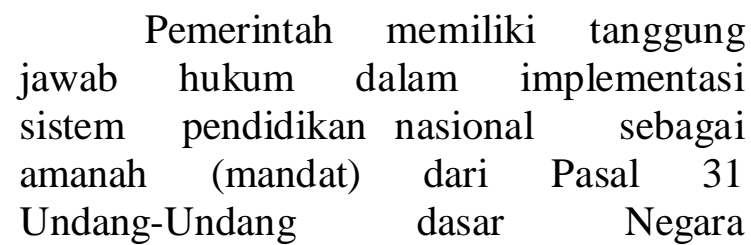
Republik Indonesia Tahun 1945 yakni hak mendapatkan pendidikan yang layak. Mandat tersebut diturunkan dalam Peraturan Pemerintah Nomor 47 Tahun 2008 tentangwajib belajar 12 tahun. Undang-Undang Republik Indonesia Nomor 20 Tahun 2003 tentang Sistem Pendidikan Nasional selanjutnya disingkat (UU Sidiknas No. 20 Th.2003). Pendidikan Nasional berfungsi mengembangkan kemampuan dan

\footnotetext{
${ }^{4}$ https://www.merdeka.com/peristiwa/60persen-guru-di-indonesia-terbatas-kuasai-teknologiinformasi-dan komunikasi.html. Diakses tanggal 8 Juli 2021.
}

membentuk watak serta peradaban bangsa yang bermartabat dalam rangka mencerdaskan kehidupan bangsa, bertujuan untuk berkembangnya potensi peserta didik agar menjadi manusia yang beriman dan bertakwa kepada Tuhan Yang Maha Esa, berakhlak mulia, sehat, berilmu, cakap, kreatif, mandiri dan menjadi warga negara yang demokratis serta bertanggung jawab ${ }^{5}$ Dalam Klasifikasi Standar Internasional Pendidikan (ISCED) yang telah dikembangkan oleh UNESCO dapat digunakan untuk membandingkan sistem pendidikan di berbagai negara melalui dua variabel lintas klasifikasi utama. Yang pertama adalah tingkat pendidikan, mulai dari anak usia dini pendidikan tinggi (tingkat 1) sampai tingkat doktor (tingkat 9). Variabel kedua adalah bidang pendidikan, untuk misalnya, sains, kesehatan, atau hukum ${ }^{6}$.

Dalam sistem pendidikan di Indonesia Sekolah Menengah Atas (SMA) adalah jenjang pendidikan menengah pada pendidikan formal di Indonesia yang dilaksanakan setelah lulus dari Sekolah Menengah Pertama (SMP) atau sederajat. Jenjang pendidikan ini dimulai dariKelas 10 sampai Kelas 12 dengan siswa yang umumnya berusia 15-18 tahun. Pada tahun pertama yakni kelas 10, siswa mendapatkan pelajaran umum. Tetapi pada tahun kedua atau Kelas 11, beberapa sekolah menerapkan siswa mereka memilih salah satu dari berbagai jurusan yang ada, seperti Sains, Sosial, Bahasa dan lain-lainnya yang kurikulumnya

\footnotetext{
${ }^{5}$ Undang-Undang Republik Indonesia

Nomor 20 Tahun 2003 tentang Sistem Pendidikan Nasional

${ }^{6}$ Organisation for Economic Co-operation and Development. (2015). ISCED 2011 operational manual. OECD, European Union, UNESCO Institute for Statistics. https://doi.org/10.1787/9789264228368-en
} 
disesuaikan dengan jurusan yang dipilihnya $^{7}$. Seperti halnya pada sekolah-sekolah lain di Indonesia, program pembelajaran yang ada pada tiap SMA saat ini menggunakan Kurikulum 13 (K-13) yang mengacu pada Standar Nasional Pendidikan. Oleh karena itu, kurikulum pada Sekolah Menengah Atas di Indonesia minimal harus memenuhi kerangka dasar kurikulum, struktur kurikulum, beban belajar serta kalender pendidikan yang telah disusun dalam Standar Isi.

Kemudian struktur dasar pendidikan guru di Indonesia belum sepenuhnya memiliki standar dan kualifikasi yang sesuai dengan latar belakang pendidikan yang mereka miliki. Guru adalah profesi yang memegang peran sentral dalam menentukan generasi penerus bangsa. Guru dituntut memiliki keterampilan yang memungkinkan untuk mengorganisasikan materi serta mengelolanya dalam pembelajaran dan pembentukan kompetensi siswa. Profesi guru harus dipersiapkan untuk mengenal ilmu pengetahuan yang luas agar memiliki kemampuan dan kompetensi. Kompetensi guru bersifat kompleks dan merupakan kesatuan yang utuh yang menggambarkan pengetahuan, keterampilan dan nilai nilai dasar yang direfleksikan melalui tindakan dalam melaksanakan tugas-tugas sebagai pendidik. Sertifikasi guru yang dilaksanakan pemerintah merupakan upaya peningkatan mutu guru yang dibarengi dengan peningkatan kesejahteraan guru. Muara akhir yang diharapkan adalah meningkatkan mutu pembelajaran dan mutu pendidikan di Indonesia secara berkelanjutan. Bentuk peningkatan kesejahteraan adalah upaya pemberian insentif tunjangan profesi guru sebesar satu kali gaji pokok setiap bulan bagi guru

\footnotetext{
${ }^{7}$ http://e-

journal.uajy.ac.id/2070/3/2TA11215.pdf
}

yang memiliki sertifikat pendidik. Dalam pelatihan guru yang dilakukan oleh pemerintah selama ini baru sebatas pelatihan pengajaran kelas praktis di sekolah belum kepada pelatihan bagaimana menggunakan tekhnologi yang baik dan menarik. Pandemi Covid-19 telah membuka mata kita semua bahwa tekhnologi memang harus dikuasai dan ditaklukkan jika guru tidak ingin dikatakan tertinggal dari siswa mereka dalam penguasaan tekhnologi, terutama pemanfaatan tekhnologi pengajaran.

\section{Pengembangan dan Digitalisasi Sekolah}

Rolff mendefinisikan pengembangan sekolah sebagai transformasi yang berkelanjutan, disengaja dan direncanakan pada seluruh jenjang sekolah, dengan melibatkan seluruh pemangku kepentingan sekolah ${ }^{8}$. Kegiatan terkait dapat berfokus pada tiga dimensi: pengajaran (misalnya, pelatihan metodis dan pembelajaran siswa), pengembangan staf (misalnya, supervisi, observasi tim, pendampingan) dan pengembangan organisasi (misalnya, manajemen sekolah, konsep sekolah, kerjasama dengan pihak ketiga). Konseptualisasi yang lebih baru termasuk infrastruktur teknologi sekolah dan kondisi sekolah ${ }^{9}$ misalnya jumlah perangkat seluler seperti tablet yang tersedia untuk siswa atau keberadaan seluruh sekolah rencana pengembangan digital, sebagai pendorong tambahan untuk pengembangan sekolah yang berkelanjutan. Pengembangan SMA harus

${ }^{8}$ Rolff, H.-G. (1995). Steuerung, Entwicklung und Qualitätssicherung von Schulen durch Evaluation. In A. Christel \& H.G. Rolff (Eds.), Zukunftsfelder von Schulforschung (pp. 375-392). DSV.

${ }^{9}$ Fraillon, J., Ainley, J., Schulz, W., Friedman, T., \& Duckworth, D. (2020). Preparing for life in a digital world. IEA Internasional Computer and Information Literacy Study 2018international report. Springer International Publishing. https://doi.org/ 10.1007/978-3-03038781-5 
mempertimbangkan banyak hal, seperti kerjasama antara lembaga pelatihan dan perguruan tinggi, baik itu negeri maupun swasta. Semakin banyak kerjasama yang dilakukan semakin besar peluang dan kesempatan lulusan SMA melanjutkan studi ke jenjang berikutnya atau dapat juga diterima di dunia kerja, walaupun hanya berbekal ijazah SMA.

Dewasa ini di lingkungan tempat kerja atau dunia kampus keterampilan digital menjadi semakin penting. Oleh karena itu SMA saat ini harus mempertimbangkan pentingnya pengusaan dan sekaligus insfrastruktur digitalisasi yang di sekolah. Sangat beralasan saat ini digitalisasi memainkan peran utama dalam program dan pelayanan pendidikan guru serta proses pengembangan sekolah. Eickelmann dan Gerick's mengusulkan kerangka teoritis yang akan pentingnya digitalisasi dalam proses pengembangan sekolah. Menurut mereka, pengembangan sekolah dapat dilakukan dengan cara seperti menitikberatkan pada pengembangan kegiatan kelas. Proses ini dapat dilakukan dengan model pengajaran dengan tablet atau menggunakan media online dalam proses pembelajaran. Kemudian juga dapat berupa pengembangan Pribadi guru, yang berkonsentrasi pada pelatihan dan kualifikasi guru dan tenaga administrasi. Dan selanjutnya pengembangan sekolah, yang meliputi tata tertib dan agenda sekolah atau program sekolah selama 1 tahun pelajaran.

Kerangka teoritis tersebut harus dipahami sebagai aspek yang saling terkait dan memiliki nilai manfaat. Investasi dengan pengadaan tekhnologi yang baru adalah pemborosan jika guru tidak terlatih untuk menggunakannya. Guru hanya dapat menerapkan metode pengajaran digital jika infrastruktur sekolah memungkinkan akses ke Internet . Model seperti ini diharapkan juga tidak hanya menekankan praktik pada guru semata, namun keterampilan siswa juga perlu dilatih. Apabila keduanya dapat berjalan bersama pembelajaran yang menyenangkan dan tidak membosankan akan terwujud dalam kondisi dan situasi apapun.

Peran kepala sekolah sebagai pemimpin juga digarisbawahi oleh Ilomäki dan Lakkala. Satu dari tugas utama kepemimpinan sekolah adalah untuk menyatukan gagasan dan ide dari semua unsur yang berbeda di sekolah, untuk mewujudkan proses pembangunan yang sedang berlangsung dan visi misi bersama $^{10}$. Di sinilah perlunya suatu kerjasama anatara kepala sekolah dengan dewan guru. Kerjasama menurut Wahjosumidjo merupakan usaha yang dilakukan agar proses kegiatan dalam mencapai tujuan dilaksanakan dengan seefektif mungkin tanpa adanya pertentangan, konflik, perbedaanperbedaan persepsi yang membahayakan kepentingan organisasi yang luas ${ }^{11}$. Untuk memaksimalkan gagasan dan ide ini maka diperlukan kelima bidang pengembangan (Pendidikan, Personalia, Organisasi, Teknologi dan Kerjasama) dalam proses digitalisasi yang sedang dan akan berlangsung dalam pengembangan sekolah.

\section{Pertanyaan Penelitian}

Menurut Iivari perubahan yang begitu cepat dan sistemik di sekolah dalam bentuk transformasi digital yang dramatis telah terjadi sebagai akibat dari pandemi

\footnotetext{
${ }^{10}$ Ilomäki, L., \& Lakkala, M. (2018). Digital technology and practices for school improvement: Innovative digital school model. Research and Practice in Technology Enhanced Learning, 13(1), 25. https://doi.org/10.1186/s41039-018-0094-8

${ }^{11}$ Wahjosumidjo. Kepemimpinan Kepala Sekolah. (Jakarta: PT Raja Grafindo Persada.2010) hlm. 474
} 
Covid-19 ${ }^{12}$, termasuk perubahan radikal dari tatap muka ke sistem pengajaran dan pembelajaran online. Teknologi dapat digunakan untuk mengimbangi beberapa dampak negatif pandemi terhadap pendidikan, tetapi keterbatasan sarana prasarana dan metode harus dipertimbangkan secara menyeluruh. Tidak terserapnya pembelajaran secara sempurna di masa pandemi banyak disebabkan oleh ketidakmampuan guru dan siswa dalam menguasai tekhnologi dan juga karena faktor-faktor yang lain diantaranya status ekonomi siswa yang kurang mampu. Singh \& Haynes menilai kompetensi kepemimpinan telah diidentifikasi sebagai faktor kunci untuk transformasi proses di lembaga pendidikan selama pandemi Covid-19. Dari asumsi yang disebutkan di atas menghasilkan pertanyaan penelitian khusus mengenai digitalisasi digital pengembangan di sekolah menengah atas.

a. Bagaimana infrastruktur teknologi mempengaruhi proses transformasi di sekolah menengah atas (SMA) ?

b. Bagaimana peran kepala sekolah dalam mempengaruhi proses transformasi ?

c. Apa faktor kunci keberhasilan dalam pembelajaran digital ?

\section{Metode Penelitian}

1. Peserta

Pada awalnya ada 20 orang yang bersedia diwawancarai. Tingkat partisipasi $50 \%$ diasumsikan berdasarkan pandemi Covid19 dan pengalaman sebelumnya dengan pengalaman pembelajaran oneline di sekolah. Lokasi sekolah ditetapkan adalah SMA Muhammadiyah 3 dan SMA Muhammadiyah 4

${ }^{12}$ Iivari, N., Sharma, S., \& VentäOlkkonen, L. (2020). Digital transformation of everyday life - How COVID-19 pandemic transformed the basic education of the young generation and why information management research should care? International Journal of Information Management, 55(6), 102183. https://doi.org/10.1016/j.ijinfomgt.2020.102183
Kota Tangerang. Di setiap sekolah, 10 orang dipilih secara acak dari daftar guru di website sekolah (satu laki-laki, satu perempuan) dan dihubungi melalui whatsapp. Ditotal, 10 guru setuju untuk berpartisipasi, dan wawancara dilakukan dengan 5 pria dan 5 partisipan perempuan. Rata-rata usia peserta adalah 34,8 tahun, dengan peserta tertua menjadi 58 dan termuda 29.

2. Instrumen dan Prosedur Penelitian

Wawancara dilakukan sebagai wawancara semi terstruktur. Di bagian pertama wawancara, di dapat data demografi peserta (misalnya, jenis kelamin, usia) dan data tentang sekolah (misalnya, ketersediaan infrastruktur teknologi). Pada bagian kedua, peserta melaporkan proses tugas pada saat pengajaran di tempat berakhir, dengan fokus pada kepemimpinan sekolah, pengajaran dan kerja sama (misalnya, agenda sekolah, metode dan alat untuk pengajaran online). Dalam setiap pertanyaan bertujuan untuk mengetahui tantangan dan langkah-langkah apa yang diambil guru untuk mengatasi tantangan mengunakan teknologi pada masa pandemi. Pada bagian terakhir, guru diminta untuk mengevaluasi keberlanjutan proses transformasi di sekolah mereka. Wawancara dilakukan secara offline dan online (zoom meeting) dan melalui telepon.

3. Analisis

Setiap hasil dari wawancara diberi kode dan dianalisis. Setiap peserta ditugaskan menjawab ke lima bidang pengembangan (Pendidikan, Personalia, Organisasi, Teknologi dan Kerjasama). Pernyataan tentang siswa dan guru tentu sangat bervariasi dan berbeda satu sama lain, dan ini mencerminkan keberagaman dan keyakinan dalam berargumentasi para peserta. Setiap pernyataan yang dipilih telah diterjemahkan dan diolah oleh penulis untuk dijadikan contoh masukan dan saran dalam proses pengembangan sekolah.

\section{Hasil Penelitian}

Sebelum pandemi Covid-19 melanda Indonesia, sebagian besar sekolah termasuk 
sekolah di Tangerang belum menggunakan sistem pembelajaran online seperti menggunakan aplikasi zoom meeting, google meeting, google class room apalagi menggunakan sistem manajemen pembelajaran (LMS). LMS yang paling umum baru diperkenalkan disebagian kecil perguruan tinggi, sedangkan aplikasi zoom meeting dan google meeting menjadi barang baru di kalangan guru. Selama ini para guru dalam proses belajar mengajar lebih banyak menggunakan power point dan vidio. Begitu juga siswa, sebagian besar siswa tidak memiliki pengalaman dengan zoom meeting dan google meeting bahkan LMS atau sistem cloud sekolah. Dalam kasus yang paling ekstrim , guru dan siswa tidak memiliki akun untuk membuat dan memperaktek aplikasi tersebut. Infrastruktur server dan jaringan internet di beberapa sekolah terbukti tidak memadai dan belum siap untuk beralih ke pengajaran online.

Selama ini sebagian besar sekolah dan guru hanya menyediakan siswa bahan ajar dan lembar latihan yang bisa diolah di rumah. Proses ini terkadang tidak efesien. Guru terkadang sering terlambat memeriksa dan mengoreksi hasil tugas siswa. Di beberapa sekolah siswa hanya bertemu guru mata pelajaran 1 kali dalam satu minggu di kelas, membuat siswa sering tidak mendapatkan penilaian oleh guru bersangkutan. Untuk mengatasi situasi ini, beberapa sekolah mengharuskan siswa memiliki . Upaya ini dilakukan agar materi pembelajaran dapat disampaikan melalui email. Setiap siswa yang memiliki email akan memudahkan mereka mengakses dan mengikuti pembelajaran serta mengerjakan tugas dari guru melalui google meeting atau google class room.

Dari hasil wawancara dan diskusi dengan guru diketahui mereka mempersiapkan materi pembelajaran mereka dan mencoba beradaftasi mengatasi situasi baru di sekolah mereka. Dalam banyak kasus, guru yang akrab dengan perangkat lunak tertentu mulai memberikan sedikit tutorial dan berbagi pengalaman kepada rekan guru yang lain mereka. Guru yang lebih muda melaporkan bahwa mereka sudah memiliki had materi bentuk digital dan mereka hanya perlu mengunggah file ke setiap aplikasi yang akan digunakan.Setelah masalah awal dengan aplikasi baru sedikit demi sedikit dikuasai, para guru dengan cepat mulai terbiasa menggunakan aplikasi pembelajaran online di sekolah mereka.

Sebagian besar peserta melaporkan penggunaan prinsip coba-coba sebagai cara awal menemukan alat dan metode pengajaran online yang memadai. Setelah membekali siswa dengan digital lembar kerja, guru mulai memperkenalkan umpan balik sukarela dari siswa. Setelah inisial ini fase, guru mulai memasukkan video kecil dan pengajaran online melalui alat konferensi video. Para peserta menyebutkan perhatian yang mereka berikan pada reaksi siswa selama ini proses. Tujuan utama guru adalah untuk menemukan metode yang mereka sendiri merasa nyaman dan yang juga membantu siswa dengan kegiatan belajar online mereka. Dalam banyak kasus, guru bertanya siswa metode mana yang mereka sukai atau jika mereka ingin mencoba sesuatu yang lain.

Para peserta melaporkan bahwa seringkali satu atau dua alat tertentu cocok dengan kepribadian mereka sendiri dan kemampuan mereka gaya mengajar terbaik. Mereka menyebutkan bahwa ini hanya berlaku untuk kelas tertentu dan alat itu mungkin tidak berguna untuk siswa atau topik lain. Selain itu, mereka mengalami heterogen umpan balik dari siswa mengenai alat pengajaran yang paling efisien. Peserta menggambarkan siswa di kelas yang sama yang secara khusus meminta konferensi video yang mirip dengan sekolah biasa pelajaran, sementara siswa lain ingin tetap dengan video pendek.

Peserta berjuang dengan siswa yang tidak menanggapi pendekatan menghubungi mereka. Itu guru menggambarkan diri mereka sebagai tidak yakin apakah siswa tersebut tidak mau atau tidak mampu berpartisipasi dalam pembelajaran online. Mereka 
mengungkapkan ketakutan tentang para siswa yang tidak dapat mengikuti dengan seluruh kelas, terutama sehubungan dengan tahun ajaran berikutnya dan siswa pelatihan profesional pada umumnya. Secara bersamaan, para peserta tidak yakin tentang bagaimana menangani situasi masa depan di mana siswa mungkin tidak dapat secara komprehensif mengikuti kelas untuk lama sekali:

Secara umum, siswa menggunakan materi yang diunggah dan muncul untuk pelajaran online, tetapi ada adalah beberapa siswa yang tidak mau atau tidak dapat berpartisipasi dalam pengajaran online. Setiap guru melaporkan siswa yang tidak dapat dihubungi sejak akhir pengajaran dan berupaya untuk menghubungi. Dari beberapa kendala yang didapat mereka rata-rata terkendala oleh lemahnya jaringan dan kuaota internet. Ada beberapa kendala seperti misalnya jika kita tidak mengaturnya saat ada pembaharuan suatu aplikasi dan data selular kita hidup maka otomatis akan terupdate sendiri dan menyedot kuota internet. Oleh karena itu program pemerintah memberi kuota gratis kepada setiap guru dan siswa sedikit agak membantu permasalahan kuota yang dihadapi para pengguna aplikasi digital.

Keberlanjutan metode dan alat pengajaran online saat ini setelah pandemi Covid-19 dinilai berbeda oleh para peserta. Mayoritas guru ingin tetap menyediakan digital materi pembelajaran kepada siswa mereka di aplikasi yang mereka pilih seperti google class room. Guru cenderung menggunakan hal yang sama dengan sedikit diperbarui karena cara ini terbukti bermanfaat untuk siswa. Mengunggah materi yang direvisi untuk kelas di tahun ajaran berikutnya dianggap sebagai cara yang efektif untuk menyediakan siswa dengan materi pembelajaran. Walaupun sebagian guru agak sedikit terlambat memahami dan menguasai tekhnologi, ternayata setelah mereka menjalaninya guru menilai digitalisasi materi dan upload sebagai proses yang tidak memakan waktu setelah mereka mengalaminya. Selain itu, mereka ingin siswa mereka segera memiliki kompetensi dalam menggunakan aplikasi belajar online dalam proses belajar mengajar. Sehingga dapat dikatakan faktor kunci keberhasilan dalam pembelajaran digital adalah semua guru dan siswa harus dapat menaklukkan tekhnologi secepat mungkin. Tekhnologi yang kita hadapi saat ini setiap saat akan selalu mengalami perubahan. Jika kita tidak mampu menguasainya maka kita akan selalu tertinggal dari bangsa lain.

\section{E. Penutup}

Pandemi Covid-19 terbukti menjadi tantangan besar bagi siswa, guru, dan pemangku kepentingan lainnya di SMA Indonesia pada umumnya. Temuan menggarisbawahi asumsi saling ketergantungan antara bidang pengembangan yang satu dengan bidang yang lain. Kondisi pandemi covid-19 memaksa setiap sekolah untuk mengubah sistem pengajaran dari offline ke online, dan ini membutuhkan ketersediaan jaringan yang internet dan SDM yang memadai. Ketika kondisi jaringan dirasa kurang menonjol, yaitu peralatan yang memadai dan struktur server yang dikelola serta kemampuan dan motivasi guru untuk merancang pembelajaran dengan alat digital. Maka harapan siswa mampu mengakses dan bekerja dengan materi online sulit akan terwujud. Dibanyak kasus, sekolah belum mampu mengatasi tantangan terkait dengan solusi yang memiliki potensi untuk diperkenalkan sebagai solusi di sekolah lain, terlepas dari Covid-19.

Kemudian kepemimpinan sekolah dan kapasitas infrastruktur teknologi struktur di sekolah juga dapat diidentifikasi sebagai faktor kunci dalam keberhasilan memulai pembelajaran online. Struktur server yang berfungsi penuh dan tenaga IT yang mumpuni juga sangat penting, dengan fokus khusus pada perlindungan dan keamanan data 
pendidikan ${ }^{13}$. Hasil penelitian menunjukkan bahwa infrastruktur IT di banyak sekolah belum diuji secara menyeluruh. Peralatan teknologi tidak cocok untuk berbagai tugas yang dihadapi, yang dapat ditafsirkan pada umumnya karena faktor anggaran yang tersedia. Selain itu IT di sekolah selama ini belum diberikan tanggung jawab kepada para ahli di luar sekolah. Masih banyak sekolah memanfaatkan tenaga guru yang kebetulan memiliki kemampuan IT lebih baik dari guru yang lain. Tampaknya para pengambil keputusan sekolah dan para pimpinan masih menganggap kurang pentingnya tenaga IT yang khusus.

Semua wawancara menunjukkan
pengaruh besar kepemimpinan dan
pengembangan sekolah terhadap
memperkenalkan pengajaran online di SMA selama pandemi Covid-19. Disekolah di mana kepemimpinan sekolah menyajikan aturan, tugas, dan persyaratan yang jelas, guru mampu bergerak lebih cepat untuk mengajar online daripada di sekolah tanpa kepemimpinan yang jelas. Penting untuk diperhatikan bahwa kepala sekolah dan para pimpinan harus sudah memulai mengubah strategi bahwa digitalisasi dalam proses pembelajaran dan pengembangan sekolah harus sudah dimulai jika tidak ingin tertinggal oleh para kompetitor sekolah-sekolah lain yang sudah lebih maju dan berkembang.

Kutipan di atas menunjukkan aspek penting lain dari pengembangan sekolah mengenai digitalisasi. Proses memperkenalkan alat dan metode digital ke dalam pengembangan sekolah bersifat vital. ini mencakup perubahan dan situasi yang sedang dihadapi sekolah, tergantung pada tantangan dan peluang yang dihadapi sekolah. Situasi selama Covid-19 yang diliput dalam wawancara menunjukkan pelatihan TIK yang tidak memadai dari banyak guru. Penggunaan

${ }^{13}$ Oberländer, M., Beinicke, A., \& Bipp, T. (2020). Digital competencies: A review of the literature and applications in the workplace. Computers \& Education, 146(4), 103752. https://doi.org/10. 1016/j.compedu.2019.103752 metode dan alat digital memainkan peran kecil dalam pendidikan pra-guru layanan. Dalam pendidikan guru selanjutnya, pentingnya digitalisasi di sekolah diperkenalkan. Dalam kesempatan wawancara menunjukkan bahwa banyak guru menahan diri untuk tidak menggunakan alat dan metode digital secara luas sebelum pandemi. Para guru harus beradaptasi dengan situasi baru dengan menemukan metode pengajaran yang cocok untuk karakteristik mereka sendiri,mata pelajaran dan siswa dalam waktu singkat. Proses pemilihan dan refleksi digital, metode dan alat pengajaran harus menjadi bagian integral dari pendidikan guru, untuk mendukung kemampuan guru. Ini sangat penting karena pada umumnya para guru lebih enggan menggunakan dan mengajar dengan alat dan metode digital.

Kesimpulannya adalah untuk membantu pemangku kepentingan di sekolah. Faktor kunci untuk keberhasilan suatu sekolah dalam situasi pandemi Covid-19 adalah menciptakan dan mengkomunikasikan setiap agenda kepala sekolah, termasuk di dalamnya mempersiapkan infrastruktur teknologi yang andal dalam upaya menerapkan metode dan alat pengajaran secara digital. Ini dilakukan agar akhir dari pembelajaran digital akan memiliki efek berkepanjangan pada proses digitalisasi di sekolah. Siswa yang kurang beruntung secara sosial dengan akses yang tidak memadai ke Internet dapat diidentifikasi sebagai masalah yang saat ini terbukti tidak terpecahkan bagi pemangku kepentingan di sekolah. Digitalisasi pengembangan sekolah harus tertanam dalam konteks sosial ekonomi yang lebih besar. Pertanyaan tentang hak warga negara untuk mengakses koneksi Internet yang kuat, penggunaan perangkat keras yang berkelanjutan, dan peran ekonomi dalam pengajaran dan pembelajaran harus ditangani untuk keberhasilan dalam rangka mewujudkan digitalisasi di sekolah.

Adapun strategi koping menurut Angolla dan Ongri pengelolaan kondisi yang menyulitkan dengan koping yang tepat dapat mengarahkan individu kepada respon 
yang adaptif. Kopingstres sangat penting untuk dimiliki setiap individu, terutama disaat individu tersebut berada pada situasi yang mengancam atau gelisah karena pandemi tidak kunjung berakhir. Menurut Gadzella dan Masten ${ }^{14}$ stres akademik merupakan persepsi seseorang terhadap stressor dan bagaimana reaksi reaksi terhadap stressor terdiri dari reaksi fisik, emosi, perilaku dan kognitif. Penulis berasumsi bahwa stress kemungkinan besar muncul khususnya dari hasil interaksi antara dosen dan mahasiswa, kecemasan pada hasil belajar yang didapatkan, ujian atau tes yang akan dihadapi, proses belajar dalam kelompok, pengaruh teman sebaya dalam belajar, kemampuan memanajemen waktu, dan persepsi mahasiswa tentang kemampuan belajar yang akan mempengaruhi kinerja akademik selama masa pandemi.

\section{DAFTAR PUSTAKA}

Fraillon, J., Ainley, J., Schulz, W., Friedman, T., \& Duckworth, D. (2020). Preparing for life in a digital world. IEA Internasional Computer and Information Literacy Study 2018international report. Springer International Publishing. https://doi.org/ 10.1007/978-3-03038781-5

Gadzella, B. M. \& Masten, W. G. (2005). An analysis of the catagories in the student-life stress inventory. American Journal of Psychological Research, 1 (1) :1-10.

http://ejournal.uajy.ac.id/2070/3/2TA11215.p df

https://www.merdeka.com/peristiwa/60persen-guru-di-indonesia-terbataskuasai-teknologiinformasi-dan

${ }^{14}$ Gadzella, B. M. \& Masten, W. G. (2005). An analysis of the catagories in the student-life stress inventory. American Journal of Psychological Research, 1 (1) :1-10. komunikasi.html. Diakses tanggal 8 Juli 2021.

Ifenthaler, D., \& Schweinbenz, V. (2013). The acceptance of tablet-PCs in classroom instruction: The teachers' perspectives. Computers in Human Behavior Journal, 29 (3), 525-534. doi:10.1016/j.chb.2012.11.004

llomäki, L., \& Lakkala, M. (2018). Digital technology and practices for school improvement: Innovative digital school model. Research and Practice in Technology Enhanced Learning, 13(1), 25. https://doi.org/10.1186/s41039-0180094-8

Jan Delcker \& Dirk Ifenthaler (2020): Teachers' perspective on school development at German vocational schools during the Covid-19 pandemic, Technology, Pedagogy and Education, DOI: 10.1080/1475939X.2020.1857826

livari, N., Sharma, S., \& Ventä-Olkkonen, L. (2020). Digital transformation of everyday life - How COVID-19 pandemic transformed the basic education of the young generation and why information management research should care? International Journal of Information Management, 55(6), 102183. https://doi.org/10.1016/j.ijinfomgt.20 20.102183

Mishra, P., \& Koehler, M. J.(2008). Introducing Technological Pedagogical Content Knowledge. Paper Presented at The Annual Meeting of American Educational Reseacrh Association. New York.

Oberländer, M., Beinicke, A., \& Bipp, T. (2020). Digital competencies: A review of the literature and applications in the workplace. Computers \& Education, 146(4), 103752. https://doi.org/10. 1016/j.compedu.2019.103752

Organisation for Economic Co-operation and Development. (2015). ISCED 2011 operational manual. OECD, European 
Union, UNESCO Institute for Statistics. https://doi.org/10.1787/97892642283 68-en

Rolff, H.-G. (1995). Steuerung, Entwicklungund Qualitätssicherung von Schulen durch Evaluation. In A. Christel \& H.G. Rolff (Eds.), Zukunftsfelder von Schulforschung (pp. 375-392). DSV.
Undang-Undang Republik Indonesia Nomor 20 Tahun 2003 tentang Sistem Pendidikan Nasional

Wahjosumidjo. Kepemimpinan Kepala Sekolah. (Jakarta: PT Raja Grafindo Persada.2010). 
Perspektif Guru Tentang Pengembangan Sma Di Tangerang Pada Masa Pandemi Covid-19.

Rausyan Fikr. Vol. 17 No.1 Maret -No.2 September 2021. ISSN. 1979-0074 e-ISSN. $9772580594187 \mid 96$ 